\title{
Child's von meyenburg complexes
}

\author{
Anna Makhneva, Bekisheva Aigul, Bulegenova Minira*and Adamova Gauhar
}

*Correspondence: mbulegenova@yandex.ru

Scientific Center of Pediatrics and Children's Surgery at the Ministry of Health of the Republic of Kazakhstan.

\begin{abstract}
Von Meyenburg complex (biliary hamartoma, microhamartoma) is extremely rare benign formation, often of a random finding due to its asymptomatic course. During ultrasound investigation and computed tomography, this pathology has to be differentiated from metastatic lesions and hepatic cirrhosis. This publication describes von Meyenburg complexes of a 3-year-old child.
\end{abstract}

Keywords: Von meyenburg complex, metastatic lesions, hepatic cirrhosis, biliary hamartoma, microhamartoma

\section{Introduction}

Abnormal development of biliary tract is among the most commonly encountered anomalies of digestive system.

In embryogenesis liver tissue and biliary system develop from the anterior part of the gut. Abnormalities of aniage and tissue differentiation are distinguished among the cases of abnormal development. Aniage abnormalities occur in the form of severe and frequently fatal structural and functional changes of organs.

From the clinical per-spective it is expedient to subdivide structural changes of biliary tract into:

1. Developmental variation, when all organ functionalities are preserved.

2. Abnormal development, when existing individual peculiarities in the organ structure slightly influence its function or manifest in the form of easily compensated disorders but at the same time under certain conditions may be the background for the secondary pathological process development.

3. Abnormality-gross changes in the structure of an organ excluding its normal functioning [1].

Structural changes of live in children with biliary abnormalities are represented by ductopenia with different degrees of manifestation, persistence of immature biliary structures and formation of biliary hamartomas [2].

Von Meyenburg complex (biliary hamartoma, microhamartoma) is extremely rare benign formation, often of a multinodular character. For the first time this case was described in 1918 $[3,4]$. According to some authors microhamartoma occurs in $0.69-5.6 \%$ autopsies and in $0.6 \%$ biopsies $[5,6]$.

It is believed that von Meyenburg complexes appear due to violations in the intrauterine differentiation of biliary structures [2].
This pathology is often of a random finding when performing autopsy due to its asymptomatic course [7]. There may be the abdomen enlargement while maintaining the normal appetite, normal temperature and the absence of other violations in the general condition. During ultrasound investigation and computed tomography this pathology has to be differentiated from metastatic lesions of the liver [8,9].

Polyarteritis nodosa sometimes leads to the formation of such complexes due to hepatic ischemia, but this disease is more characteristic of the formation of multiple saccular aneurysms in small arteries.

Macroscopic observe shows grayish-white or grayish-yellow nodules, single or multiple, up to $10 \mathrm{~mm}$ in diameter, usually scattered on both lobes of the liver, especially in the subcapsular area. Periportal position is also typical. Lesions reaching $16 \mathrm{~cm}$ in volume are described, such cases bear evidence to biliary adenofibroma [5].

Histological investigation of hepar tissue shows limited assembly of bile ducts located in the fibrous, sometimes hyalinized stroma [4]. Inlayed with low cuboidal epithelium, ducts may be irregular-shaped, extended with cysts, and may contain bile or proteinaceous substance [10].

Besides, U-shaped or branching ducts may take place. In rare cases ducts may develop up to onset of microscopic cystis covered by low columnar/cuboidal epithelium and contain amorphous material [10].

Von Meyenburg complexes should be differentiated between hepatic adenoma, polycystic liver disease and congenital hepatic fibrosis.

Hepatic adenoma is a tumour having sharp contours, sarcous consistency and well-marked superficial vascular patterns. In most cases adenoma diameter is $8-15 \mathrm{~cm}$. Physical signs of 
Makhneva et al. Journal of Histology \& Histopathology 2015,

http://www.hoajonline.com/journals/pdf/2055-091X-2-15.pdf

doi: 10.7243/2055-091X-2-15

hepatic adenoma are rather variable: from hypo- to hyperchoic lesions at ultrasonic scanning and from hypo- (low density) to hyperdense (high density) lesions at CT. Image contrast intensification can be marked at CTH. An increased density of tumour central areas represented by focuses of haemorrhage say for the suspected diagnosis. MRT in this case is a nonspecific diagnostic technique. Microscopically hepatic adenoma consists of normal- or small-sized hepatocyte layers without biliary ducts, portal lobules and central veins between them. Fibrous septum and Kupffer cells cannot be visualized.

In case of congenital hepatic fibrosis thick collagenous bunches form a vast network, usually continuous, connecting adjoining portal tracts. Fibrous septas contain great many structures similar to biliary ducts; some of them are slightly abrupt and expanded and sometime contain mucin and bilis. In spite of the fact that these structures resemble biliary ducts, in fact they represent remnants of ductal plate. Reduction in size and number of portal vein branches is often observed. Irregular parenchyma between fibrous septas frequently has a mosaic structure without signs of parenchyma destruction or regeneration; there is an abrupt junction between normal form hepatocytes and collagenous septas.

Infantile cyctic disease is an autosomal-recessive medical condition with varied clinical presentation. In case of cystic disease liver is increased and dense but cystic lesions are usually invisible microscopically. Multiple abrupt duct-like structures in portal areas are distinguished by microscopy. They have visible branching and abrupt angulous developments passing into acinuses, often there is a circular pattern of ducts, whole or interrupted, which is characteristic of duct plate malformation. In contrast with von Meyenburg complexes relatively little amount of fibrous tissue is observed [11].

At present English-language literatures report about more than 30 cases of transformation of von Meyenburg complexes into Intrahepatic cholangiocarcinoma [12-15].

\section{Case presentation}

The Scientific Center of Pediatrics and Children's Surgery admitted 3-year-old girl named K., complaining of abdomen enlargement, periodically unstable stool and increased appetite. Abdomen enlargement appeared at the age of 4 months.

Data of the objective examination: weight $12.5 \mathrm{~kg}$, height $86 \mathrm{~cm}$. Skin cover is pale pink, clean, rashes were not found, moderate venous network on the anterior abdominal wall, muscle tone is moderately reduced. Stomach is increased due to hepatosplenomegaly, liver protrudes from under the costal arch: right lobe $\pm 3 \mathrm{~cm}$, left lobe $\pm(4-5.5) \mathrm{cm}$, spleen $\pm(1.0-1.5)$ $\mathrm{cm}$ from under the costal arc.

According to laboratory studies: anemia, thrombocytopenia, hypofibrinogenemia and hypercholesterolemia.

Ultrasound investigation and computed tomography of the abdominal organs: liver is increased in volume (right lobe- $4.0 \mathrm{~cm}$ from under the costal margin), the inhomogeneous structure of the liver has multiple areas hyperechogenicity, boundaries are clear, rough. Intrahepatic bile ducts are moderately distended. Vascular walls of the portal vein system are dilated, collateral vessels are visualized and blood flow velocity is reduced to $6 \mathrm{~mm} / \mathrm{s}$. There is a small exudate in the gallbladder bed, pericholecystic edema of the gallbladder walls. Gallbladder is elongated, the bile is non-homogenous, no radiopaque shadows. Spleen $\pm 1.2 \mathrm{~cm}$ from under the costal margin.

According to echocardiography, heart cavity is dilated, hypertrophy of all walls of the ventricles. Myocardial contractility is reduced. Front and rear walls of the mitral valve are "fimbriated". Signs of carditis and residual effects of exudative pericarditis.

In order to perform differential diagnosis with hepatic cirrhosis, fine-needle biopsy of the liver was done.

\section{Materials and methods}

Hepatic punctate $1.6 \mathrm{~mm}$ long, less than $0.2 \mathrm{~mm}$ in diameter, with smooth contours, fixed in $10 \%$ neutral buffered formalin, dehydrated in the solution based on isopropyl alcohol IsoPrep (BioVitrum, Russia), embedded in a paraffin medium HISTOMIX ${ }^{\circledR}$ EXTRA, $54^{\circ} \mathrm{C}$ (BioVitrum, Russia); the paraffin sections 2 microns in thickness were prepared on the microtome Microm HM340E (Thermo SCIENTIFIC, Germany), clarified in the solution «BioClear» (Bio-Optica, Italy), stained with Mayer's hematoxylin (Bio-Optica, Italy) and Eosin Y 1\% aqueous solution (Bio-Optica, Italy) using the common method.

\section{Results \\ Microscopically}

Liver tissue with three transverse layers of connective tissue containing a limited assembly of irregularly dilated bile ducts. Bile ducts are inlayed with cuboidal epithelium. Hepatocytes are in the state of fatty degeneration, there are single bile thrombi (Figures 1 and 2).

The morphological picture corresponds to multiple micro hamartomas of bile ducts (von Meyenburg complexes).

According to the examination, clinical diagnosis was: "microhamartomas of bile ducts".

\section{Discussion and conclusion}

A case described herein is of special interest for pathologists and paediatric physicians due to abnormality infrequency. It should be borne in mind that von Meyenburg complexes often do not provide clinical presentation, being therefore an incidental finding, and do not always show typical results of visualization at US and CT investigation. In such cases a precise diagnosis is possible only in case of histologic examination. Von Meyenburg complexes can be supposed in case of detection in liver bioptats of localized aggregates of distended bile ducts in loose conjunctive tissue covered by cubical epithelium. This abnormality requires differential diagnostics between polycystic liver disease, hepatic adenoma and congenital hepatic fibrosis. Besides, patients with von 


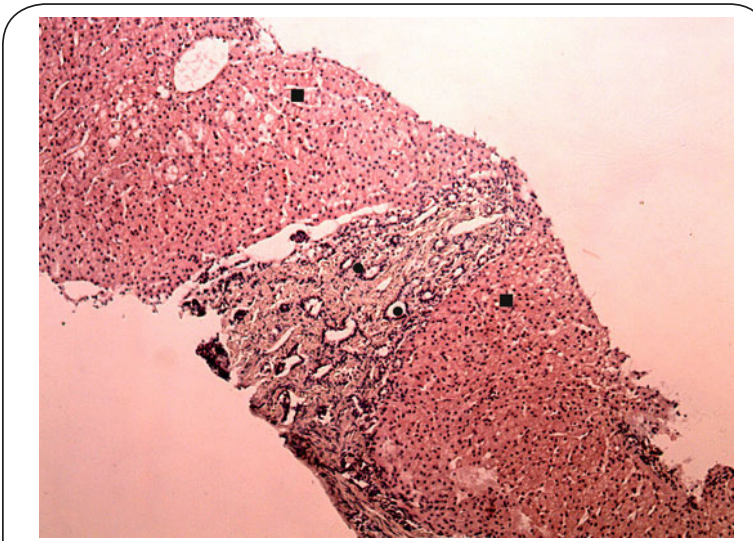

Figure 1. -Hepatocytes are in the state of fatty degeneration.

-Irregularly positioned dilated bile ducts. Hematoxylin and eosin stain, magnification x100.

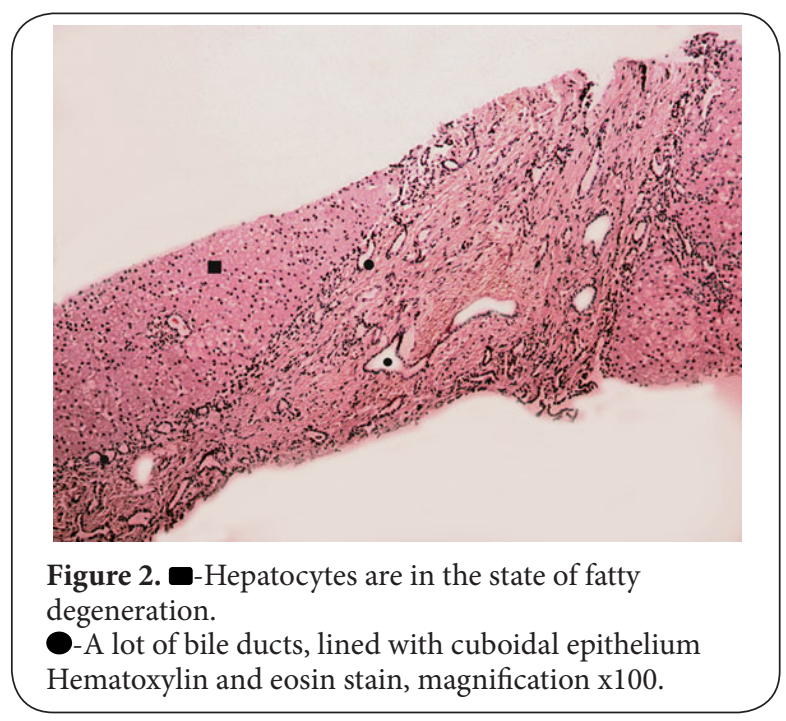

Meyenburg complexes require case follow-up due to possible transformation into Intrahepatic cholangiocarcinoma.

Novelty of the medical case reported by us lies in the fact that this patient with von Meyenburg complexes required a differential diagnostics between hepatic cirrhosis.

\section{Competing interests}

The authors declare that they have no competing interests.

\section{Authors' contributions}

\begin{tabular}{|l|c|c|c|c|}
\hline Authors' contributions & AM & BA & BM & AG \\
\hline Research concept and design & $\checkmark$ & $\checkmark$ & -- & -- \\
\hline Collection and/or assembly of data & $\checkmark$ & $\checkmark$ & -- & $\checkmark$ \\
\hline Data analysis and interpretation & $\checkmark$ & $\checkmark$ & -- & $\checkmark$ \\
\hline Writing the article & $\checkmark$ & $\checkmark$ & -- & -- \\
\hline Critical revision of the article & -- & -- & $\checkmark$ & -- \\
\hline Final approval of article & -- & -- & $\checkmark$ & -- \\
\hline Statistical analysis & -- & -- & -- & -- \\
\hline
\end{tabular}

\section{Publication history}

Editors: Fratoni Stefano, St.Eugenio Hospital of Rome, Italy. Giuseppe Musumeci, University of Catania, Italy. Received: 12-Feb-2015 Final Revised: 21-May-2015

Accepted: 29-May-2015 Published: 05-Jun-2015

\section{References}

1. Zaprudnov A Bogomaz $L$ and Haritonova L. Anomalii biliarnogo tracta u detei; RMS. Meditsinskaya Gazeta. 2005; 78.

2. Freind GG. Morphogenes duodenopankreatobiliarnyh anomaliy u detei. Avtoreferat diss. k.m.n. SPb. 2004; 22.

3. Galperin E and Dyuzheva T. Lectsii po hepatopancreatobiliarnoy hirurgii s CD. M. Vidar. 2011; 536

4. Von Meyenburg H. Uberdie Cystenleber. Beitr Pathol Anat. 1918; 64:447532.

5. Chung EB. Multiple bile-duct hamartomas. Cancer. 1970; 26:287-96. | Article | PubMed

6. Thommesen N. Biliary hamartomas (von Meyenburg complexes) in liver needle biopsies. Acta Pathol Microbiol Scand A. 1978; 86:93-9. | Article I PubMed

7. Luo TY, Itai Y, Eguchi N, Kurosaki Y, Onaya H, Ahmadi Y, Niitsu M and Tsunoda HS. Von Meyenburg complexes of the liver: imaging findings. $J$ Comput Assist Tomogr. 1998; 22:372-8. | Article I PubMed

8. Cooke JC and Cooke DA. The appearances of multiple biliary hamartomas of the liver (von Meyenberg complexes) on computed tomography. Clin Radiol. 1987; 38:101-2. | Article I PubMed

9. Iha H, Nakashima Y, Fukukura Y, Tanaka M, Wada Y, Takazawa T, Nakashima $\mathrm{O}$ and Kojiro $\mathrm{M}$. Biliary hamartomas simulating multiple hepatic metastasis on imaging findings. Kurume Med J. 1996; 43:231-5. | Article | PubMed

10. Alan G. Rose. Atlas of Gross Pathology With Histologic Correlation. Cambridge University Press. 2008; 672.

11. Peter R McNally. GI/Liver Secrets Plus. Kindle Edition. 2014; 688.

12. Kim HK and Jin SY. Cholangiocarcinoma arising in von Meyenburg complexes. Korean J Hepatol. 2011; 17:161-4. | Article I PubMed Abstract | PubMed Full Text

13. Jain D, Sarode VR, Abdul-Karim FW, Homer R and Robert ME. Evidence for the neoplastic transformation of Von-Meyenburg complexes. Am J Surg Pathol. 2000; 24:1131-9. | Article | PubMed

14. Papadogiannakis N, Gad A, Sjostedt S, Tour R, Thorne A and Seensalu R. Adenocarcinoid of the liver arising within an area of hamartoma with predominant bile duct component. J Clin Gastroenterol. 1996; 23:14551. | Article | PubMed

15. Zheng $R Q$, Zhang $B$, Kudo $M$, Onda $H$ and Inoue $T$. Imaging findings of biliary hamartomas. World J Gastroenterol. 2005; 11:6354-9. | Article | PubMed Abstract | PubMed Full Text

\section{Citation:}

Makhneva A, Aigul B, Minira B and Gauhar A. Child's von meyenburg complexes. J Histol Histopathol. 2015; 2:15. http://dx.doi.org/10.7243/2055-091X-2-15 